\title{
PENGARUH FREKUENSI PENGGANTIAN SEKAM DENGAN KEHADIRAN EKTOPARASIT PADA MENCIT (Mus musculus)
}

\author{
Armansyah Maulana Harahap ${ }^{1)}$,Endang Sulistyarini Gultom ${ }^{2)}$ Ahmad Shafwan S. Pulungan ${ }^{2)}$ \\ ${ }^{1}$ Laboratorium Biologi, FMIPA, Universitas Negeri Medan \\ 2 Jurusan Biologi, FMIPA, Universitas Negeri Medan \\ Email : armansyah.maulanahr@gmail.com
}

\begin{abstract}
ABSTRAK
Tujuan dari penelitian ini adalah untuk mengetahui pengaruh frekuensi penggantian sekam terhadap kehadiran ektoparasit pada mencit yang dilakukan di Laboratorium Biologi Universitas Negeri Medan. Metode yang digunakan dengan memakai mencit dengan frekuensi penggantian sekam sekali dua minggu dengan 3 kali pengulangan dan menggunakan mencit peliharaan dengan frekuensi penggantian sekam sekali dua hari sebagai pembanding kehadiran ektoparasit pada mencit. Badan Mencit di usap dengan kapas yang sudah ditetesi alkohol dan disisir ke atas alkohol 70\% sebagai koleksi ektoparasit kemudian di preservasi untuk di identifikasi. Hasil yang diperoleh terdapat ektoparasit jenis tungau dan pinjal untuk jenis tungau berasal dari anggota Laelapidae dan Xenopsylla cheopis pada mencit dengan frekuensi penggantian sekam sekali dua minggu, untuk itu dapat diperoleh kesimpulan bahwa kehadiran ektoparasit berpengaruh dengan frekuensi penggantian sekam.
\end{abstract}

Kata kunci: Mencit, Ektoparasit, Sekam

\section{EFFECT REPLACMENT FREQUENCY OF HUSK FOR ECTOPARASITES PRESENCE ON THE MICE (Mus musculus)}

\begin{abstract}
The purpose of this research is to know the effect of frequency of replacement of husk to the presence of ectoparasite in mice done in Biology Laboratory of State University of Medan. Method used by using mice with frequency of replacement husk once two weeks with 3 times repetition and using pet mice with frequency replacement of husk Once two days to compare the presence of ectoparasites in mice, the mice were inhaled with chloroform and then the swabs were rubbed with cotton which had been spilled with alcohol and combed onto 70\% alcohol as the ectoparasite collection then preserved for identification. The results obtained were ectoparasites of mites And fleas for mites originated from the members Laelapidae and Xenopsylla cheopis in mice with the frequency of replacement chaff once two weeks, for it can be concluded that the presence of ectoparasite affects the frequency of replacement of chaff.
\end{abstract}

\section{Keywords : Mice,Ectoparasites,Husk}

\section{Pendahuluan}

Mencit merupakan hewan pengerat yang dapat menjadi hospes reservoir bagi parasit. Mencit memiliki daerah persebaran dan resistren hidup di daerah yang gelap, kotor, lembab, serta terdapat bahan makanan. Mencit bersifat omnivora yang dapat memakan sayuran,buahbuahan maupun makanan manusia. Mencit banyak dipelihara manusia dengan keadaan kandang yang kurang terperhatikan dan dengan jumlah yang berlebih dalam satu kandang sehingga penularan parasit dari mencit kepada manusia sangat menungkinakan dikarenakan mencit merupakan hewan peliharaaan manusia. Sumanggi et al (2012) Menyatakan bahwa telah terjadi kurang lebih 40 kasus penyakit yang disebarkan oleh mencit, termasuk penyakit plag, arena, virus hanta, tiphus, helmianthasis, schistosomiasis, dan cacing paru. Penyakit-penyakit tersebut dilaporkan telah menyebabkan kematian banyak orang.

Parasit pada mencit seperti golongan parasit cacing, bakteri, maupun protozoa dapat ditularkan kepada manusia melalui ektoparasit. Ektoparasit yang menginfeksi bagian luar tubuh hospesnya sebagian besar adalah dari golongan insekta dan arachnida seperti tungai, caplak, kutu, sengkenit, dan pinjal. Ektoparasit tersebut dapat menimbulkan penyakit seperti pes, sampar, scabies, tipus, dan sebagainya dengan cara menginfeksi hospes secara langsusng maupun menjadi vektor penyakit, Oleh karena itu perlu dilakukan identifikasi ektoparasit pada tikus untuk mengetahui potensi penularan penyakit dari tikus kepada manusia sehingga kemudian dapat menjadi 
informasi untuk melakukan pengendalian terhadap keberadaan ektoparasit tersebut.

Penelitian ini dilakukan di Laboratorium Biologi Universitas Negeri Medan dengan sampel yang di ambil langsung dari Rumah Hewan FMIPA UNIMED karena tempat ini merupakan tempat pemeliharaan mencit yang dijadikan sebagai bahan untuk penelitian mahasiswa yang berpotensi menjadi penyakit. Ektoparasit dapat menimbulkan kerugian pada inangnya, yaitu terjadinya iritasi, kegatalan serta gejala lain yang mengindikasikan kondisi ketidaknyamanan. Selain itu, ektoparasit juga dapat sebagai vektor berbagai macam agen penyakit. Tubuh inang digunakan sebagai tempat untuk berkembang biak serta bertahan hidup.

Keberadaan ektoparasit ini mempengaruhi kesehatan mencit sebagai hewan coba. Ektoparasit yang terdapat pada mencit juga dapat berperan sebagai vector berbagai macam agen penyakit. Mencit juga berperan dalam penyebaran penyakit zoonosis, seperti leptospirosis, salmonellosis, ratbite fever, leishmaniasis, dan plague (Kia et al. 2009).Mencit rentan terhadap penyakit infeksius yang disebabkan oleh bakteria, virus, parasit, dan jamur. Beberapa penelitian yang telah dilakukan menunjukkan penyakit yang terdapat pada Mencit seperti plague, tripanosomiasis, dan merupakan reservoir alami penyebab epidemic haemorrhagic fever (EHF) virus (Su et al. 1989; Coutinho dan Linardi 2007; Wei et al. 2010). Selain itu, tikus di alam juga dapat dijadikan sebagai indikator kehadiran dan dispersal dari enam agen mikroba zoonotik, seperti Rickettsia typhi, R. Conorii, Toxoplasma sp., Coxiella burnetti, Bartonella henselae, dan Leishmania infantum (Anna et al. 2010). Selain mempengaruhi kesehatan Mencit, keberadaan ektoparasit juga dapat mempengaruhi hasil dari penelitian yang menggunakan mencit sebagai hewan coba. Oleh karena itu, sangat penting diketahui jenis-jenis ektoparasit yang terdapat pada mencit sebagai hewan coba. Info mengenai jenis-jenis ektoparasit pada tikus ini belum pernah ditemukan sehingga penelitian ini diperlukan. Penelitian ini bertujuan untuk mengetahui hubungan frekuensi penggantian sekam dengan kehadiran ektoparasit pada pada Mencit (Mus musculus) sebagai hewan coba.

\section{Bahan dan Metode \\ Bahan, alat dan cara kerja}

Mencit yang terdapat di rumah hewan fmipa unimed yang dijadikan sebagai hewan uji coba penelitian dengan dua perlakuan yang berbeda yaitu mencit dengan frekuensi penggantian sekam sekali dua minggu dengan mencit peliharaan di rumah dengan frekuensi penggantian sekam dua hari, mencit yang dijadikan sebagai sampel dikorbankan dengan metode inhalasi menggunakan kloroform. Kemudian mencit disisir untuk koleksi ektoparasit. Ektoparasit yang didapat dipreservasi dalam alkohol 70\% dan kemudian dibuat preparat untuk pengamatan mikroskopis. Pembuatan preparat Ektoparasit jenis tungau dilakukan dengan menggunakan objek glass yang ditutup dengan cover glass yang sudah ditetesi methylen blue untuk memperjelas hasil pengamatan kemudian diamati dibawah mikroskop.

\section{Hasil dan Pembahasan}

Pada penelitian ini menggunakan tiga ekor mencit jenis Mus sp. Setelah dilakukan penyisiran dan identifikasi menggunakan literatur Parasitologi kedokteran dan atlas helmintologi dengan mengidentifikasi berdasarkan morfologi, diketahui bahwa pada mencit yang diidentifikasi terdapat ektoparasit berupa berupa tungau dan pinjal yaitu dari tungau anggota dari Laelapidae dan dari pinjal Xenopsylla cheopis.

Tabel 1. Eektoparasit pada mencit yang dijadikan sebagai hewan uji coba

\begin{tabular}{clll}
\hline No & Sampel & Ektoparasit & Jumlah \\
\hline $\mathbf{1}$ & Mencit X & Laelapidae & 2 \\
& & Xenopsylla cheopis & 6 \\
$\mathbf{2}$ & Mencit X & Xenopsylla cheopis & 6 \\
$\mathbf{3}$ & Mencit X & Xenopsylla cheopis & 4 \\
& & Laelapidae & 2 \\
$\mathbf{4}$ & Mencit Y & Tidak ditemukan & - \\
\hline \multirow{2}{*}{ Keterangan } & : & Mencit X & :Mencit uji coba(penggantian sekam sekali dua minggu)
\end{tabular}




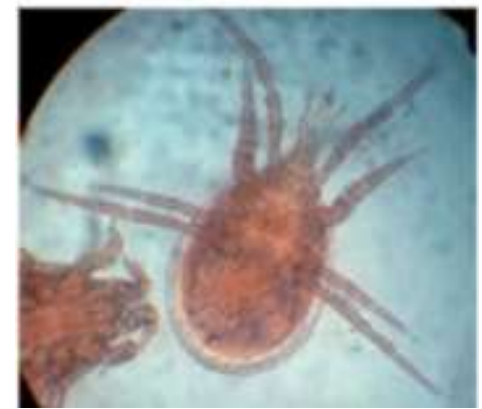

Anggota Laelapidae

Berdasarkan tabel dapat disimpulkan bahwa mencit dengan perlakuan penggantian sekam sekali dua minggu lebih banyak terdapat ekroparasit ciri fisik dari mencit juga menunjukkan keadaan rambut lebih kering dibandingkan dengan mencit peliharaan dengan frekuensi penggantian sekam dua kali sehari. Ukuran tubuh juga memperlihatkan perbedaan yaitu tubuh mencit dengan frekuensi penggantian sekam sekali dua minggu lebih kurus dan terdapat banyak bekas luka dibandingkan dengan mencit peliharaan dengan frekuensi penggantian sekam dua kali sehari. Sekam dengan frekuensi sekali dua minggu penggantian mengakibatkan kandang menjadi lembab, mengandung bau menyengat sehingga mengundang parasit jenis tungau dan pinjal untuk hadir dan menginfeksi hospesnya berupa mencit.

Untuk identifikasi dari jenis tungau pada hasil pengamatan tidak dapat di identifikasi sampai dengan tingkat spesies dikarenakan karena bentuk yang tidak begitu bagus dalam preparat identifikasi dilakukan pada tingkat morfologi meliputi alat gerak, ukuran tubuh, dan bentuk tubuhnya dan pada umumnya Laelapidae berperan sebagai parasit pada vertebrata dan mampu berperan sebagai faktor zooonosis.

Menurut (Djaenuddin,2009) Kelompok tungau ini berukuran relatif kecil, memiliki panjang kurang dari $1 \mathrm{~mm}$. Namun ada pula tungau besar yang dapat mencapai panjang $7 \mathrm{~mm}$. L. echidninus memiliki gnathosoma terdiri dari epistoma, tritosternum (berfungsi dalam transport cairan tubuh), palpus yang beruas-ruas, kelisera, kornikuli, hipostoma berseta yang masing-masing sangat beragam dalam hal bentuk dan jumlah ruasnya tergantung pada kelompoknya. Kelisera pada L. echidninus teradaptasi untuk menusuk, menghisap atau mengunyah. Tubuh dilindungi oleh dorsal shield/scutum. L. echidninus memiliki stigma (alat pertukaran 02 dan C02) yang letaknya bervariasi yaitu di punggung dorsal, antara pangkal tungkai/koksa ke-2 dan ke-3, di sebelah koksa ke-3 atau di antara kelisera. Letak stigma menjadi kunci penting untuk membedakan ordo tungau

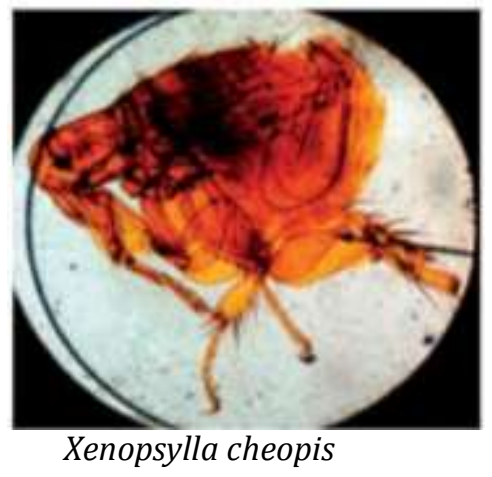

Ektoparasit jenis pinjal yang ditemukan yaitu Xenopsylla cheopis. Pinjal ini bermetamorfosis sempurna dan makan dengan menghisap darah hospesnya. Ketika pinjal menghisap darah, maka pinjal kan mengekuarkan saliva untuk mengeluarkan terjadinya koagulasi darah.Hospes yang di infeksi oleh pinjal dapat mengalami pembengkakan pada kulit dan kulit menjadi kemerah-merahan. Pinjal berperan penting dalam vektor penyebab penyakit zoonosis. Xenopsylla cheopis dapat mentransmisikan bakteri Yersinia pestis dan Ricketsia mooseri dari tikus kemanusia. Mikroorganisme tersebut dapat menyebabkan penyakit pest atau plag dan tipus.

Berdasarkan Hidajati (2013) Xenopsylla cheopis merupakan mikroorganisme yang bersifat parasit yang menumpang hidup pada daerahdaerah yang lembab dan menjangkit hospesnya dengan cara melompat. Secara umum pinjal ini hidup sebagai parasit pada hewan berambut seperti tikus ladang, anjing, dan babi bersarang diantara rambut tikus. Metamorfosis yang di alami adalah metamorfosis sempurna. Ciri Morfologi dari Xenopsylla cheopis tubuhnya kecil, pipih laterolateral, pada sekitar daerah mata terdapat bulu mata, mempunyai sepasang antena, toraks terdiri dari tiga segmen dan abdomen 10-12 segmen, mempunyai kaki-kaki yang panjang dan kuat untuk melompat terutama untuk kaki yang paling belakang, kepalanya agak pendek dan membulat. Xenopsylla cheopis berperan sebagai hospes perantara Hymenolepis diminuta dan sebagai vektor penyakit pes.

Menurut Susanti (2001), kehidupan pinjal dipengaruhi oleh beberapa faktor, diantaranya adalah :

1. Suhu dan Kelembaban. Perkembangan setiap jenis pinjal mempunyai variasi musiman yang berbeda-beda. Udara yang kering mempunyai pengaruh yang tidak menguntungkan bagi kelangsungan hidup pinjal. Suhu dalam sarang tikus lebuh tinggi selama musim dingin dan lebih tendah selama musim panas daripada suhu luar. Suhu didalm dan diluar sarang 
memperlihtkan bahwa suhu didalam sarang cncerung berbalik dengan suhu luar.

2. Cahaya. Beberapa jenis pinjal menghindri cahaya (fototaksis negatif). Pinjal jenis ini bisaanya tidak mempunyai mata. Pada sarang tikus yang kedalamannya dangkal populasi tidak akan ditemukan karena sinar matahari mampu menembus sampai dasar liang. Sedangkan pada sarang tikus yang kedalamannya lebih dalam dan mempunyai jalan yang berkelok, sinar matahari tidak dapat menembus sampai ke dasar liang. Sehingga pada sarang tikus ini banyak ditemukan pinjal.

3. Bakteri Yersinia pestis di dalam tubuh pinjal merupakan parasit pinjal yang mempengaruhi umur pinjal. Pinjal yang mengandung bakteri pes pada suhu 10150C hanya bertahan hidup selama 50 hari, sedangkan pada suhu 270C betahan hidup selama 23 hari. Pada kondisi normal, bakteri pes akan berkembang cepat, kemudian akan menyumbat alat mulut pinjal, sehingga pinjal tidak bisa menghisap darah dan akhirnya mati.

4. Predator pinjal alami merupakan faktor penting dalam menekan populasi pinjal di sarang tikus. Beberapa predator seperti semut dan kumbang kecil telah diketahui memakn pinjal pradewasa dan pinjal dewasa.

Menurut (Wicaksono,2014) Kehadiran dari pinjal dalam kandang mencit disebabkan karena kelembapan, Suhu berperan penting dalam mengatur jalannya reaksi metabolisme bagi semua makhluk hidup. Khususnya bagi mikroorganisme seperti parasit, suhu lingkungan yang berada lebih tinggi dari suhu yang dapat ditoleransi akan menyebabkan denaturasi protein dan komponen sel esensial lainnya sehingga sel akan mati. Demikian pula bila suhu lingkungannya berada di bawah batas toleransi, membran sitoplasma tidak akan berwujud cair sehingga transportasi nutrisi akan terhambat dan proses kehidupan sel akan terhenti Pada umumnya, mikroorganisme parasit memerlukan kelembaban relatif yang cukup tinggi, kira-kira $85 \%$. Kelembaban relatif dapat didefinisikan sebagai kandungan air yang terdapat di udara. Pengurangan kadar air dari protoplasma menyebabkan kegiatan metabolisme terhenti, misalnya pada proses pembekuan dan pengeringan. Cahaya merupakan salah satu faktor yang mempengaruhi pertumbuhan parasit. Secara umum, hewan parasit dan mikroorganisme lainnya dapat hidup dengan baik pada paparan cahaya normal. Akan tetapi, paparan cahaya dengan intensitas sinar ultraviolet (UV) tinggi dapat berakibat fatal bagi pertumbuhannya. Radiasi pada kekuatan tertentu dapat menyebabkan kelainan dan bahkan dapat bersifat letal bagi makhluk hidup, terutama bakteri. Sebagai contoh pada manusia, radiasi dapat menyebabkan penyakit hati akut, katarak, hipertensi, dan bahkan kanker. Akan tetapi, terdapat kelompok bakteri tertentu yang mampu bertahan dari paparan radiasi yang sangat tinggi, bahkan ratusan kali lebih besar dari daya tahan manusia tehadap radiasi, yaitu kelompok Deinococcaceae. Sebagai perbandingan, manusia pada umumnya tidak dapat bertahan pada paparan radiasi lebih dari 10 Gray (Gy, 1 Gy = $100 \mathrm{rad}$ ), sedangkan bakteri yang termasuk dalam kelompok ini dapat bertahan hingga 5.000 Gy. Pada umumnya, paparan energi radiasi dapat menyebabkan mutasi gen dan putusnya rantai DNA. Apabila terjadi pada intensitas yang tinggi, bakteri dapat mengalami kematian. Deinococcus radiodurans memiliki kemampuan untuk bertahan terhadap mekanisme perusakan materi genetik tersebut melalui sistem adaptasi dan adanya proses perbaikan rantai DNA yang sangat efisien. Sehingga menguntungkan bagi perkembang biakan dari parasit seperti pinjal dan memungkinkan pinjal dapat berkembang biak dengan baik. Kandang mencit memiliki sedikit fenetrasi cahaya, dengan keadaan kandang yang lembab dan kurangnya predator alami yang dapat memakan pinjal akan menjadi faktor pertumbuhan yang baik buat pinjal.

\section{Kesimpulan}

Dari hasil penelitian yang telah dilaksanakan, dapat diperoleh kesimpulan sebagai berikut :

1. Berdasarkan hasil penelitian yang dilakukan dapat disimpulkan bahwa Ektoparasit yang ditemnukan pada mencit uji coba dengan Frekuensi penggantian sekam ditemukan ektoparasit tungai dan pinjal yaitu Xenopsylla cheopis dan Laelapidae.

2. Xenopsylla cheopis adalah spesies paling melimpah pada semua mencit dengan frekuensi penggantian sekam dua kali seminggu

3. Ektoparasit yang ditemukan berperan sebagai penghisap darah dan sekret tikus, dapat menginfeksi manusia dan menyebabkan dermatitis dan berpotensi menjadi vektor penyebab penyakit tipus

4. Frekuensi penggantian sekam berpengaruh penting terhadap kehadiran ektoparasit pada mencit hal ini dibuktikan dengan ciri fisik dengan berat badan yang berbeda dengan mencit yang melakukan frekuensi penggantian sekam dengan dua kali sehari mempunyai badan yang gemuk untuk ciri rambut juga mempunya perbedaan dimana pada mencit 
yang mendapatkan perlakuan penggantian sekam dua kali semingu memiliki rambut yang begitu kering.

\section{Ucapan Terimakasih}

Terimakasih kepada Pihak Laboratorium Biologi FMIPA UNIMED yang telah menyediakan tempat, alat dan bahan untuk melakukan proses penelitian ini.

\section{Daftar Pustaka}

Adiyati,P.N.2011.Ragam Jenis Ektoparasit pada Hewan Uji Coba Tikus Putih (Rattus novergicus) Galur Sprague Dawley.Institut Pertanian Bogor.Bogor

Anonim.2012.Investigation of Specimen for Ectoparasites. http://www.hpa.org.uk/SMI di akses tanggal 23 Mei 2017 pukul 10:51

Baker,E.W,.G.W.Warthon.2012.An Introduction to Acarology.The Macmillan Company.New York.p: 86,97;229-331

Hidajatai,Sri.2013.Atlas

Parasitologi Kedokteran.Jakarta:EGC

Sumangali,K.,R.P.V.J.Rajapakse,R.S.

Rajakurna.2012.Urban Rodents as Potential Reservoirs of Zoonoses: a parasitic survey in two selectes areas in Kandy district.Ceylon Journal of Science.Vol 41(1).

Susanti, M. 2001. Infestasi Pinjal Ctenocephalides felis (Siphonaptera : Pulicidae) Pada Kucing Di Bogor. Bogor : IPB

Djaenuddin,Natadisastra.2009.Parasitologi Kedokteran ditinjau dari Organ tubuh yang diserang.Jakarta:EGC

Wicaksono,Ario wisnu.2014.Pengaruh kelembapan,Temperatur dan $\mathrm{pH}$ terhadap penurunan oil an grease pada proses remediasi dengan menggunakan bakteri Bacillus sp dan Bulking sekam padi. Jurnal veteriner. Vol 1(2) hal 27-34:2014 